\title{
Early childhood education in Aotearoa in a post-Covid world
}

\author{
Linda Mitchell
}

University of Waikato

This article draws on recent research on the impact of Covid-19 on the early childhood education (ECE) sector in Aotearoa. It discusses the innovative ways that ECE services found to communicate with families and children and maintain an education programme during lockdowns, the essential role they played in childcare for children of essential workers, and the approaches some took to "working in solidarity" with children, families, and community. The article discusses crucial issues that need attention at policy and organisational levels. These include new issues that arose during lockdowns, and enduring issues that have intensified. The consequences of three decades of neoliberalism, privatisation and marketisation are briefly discussed and a reimagined vision is put forward.

Keywords: early childhood education policy, neoliberalism, Covid-19, participatory democracy

\section{Context}

Covid-19 was first identified in Aotearoa New Zealand in January 2020. An Alert System designed "to manage and minimise the risk of Covid-19 in New Zealand" (New Zealand Government, 2020) was announced in March. The aim was to act quickly to eliminate Covid-19. During 2020, Alert Level 4, in place from 25 March to 27 April 2020, was a "Lockdown" where people were instructed to stay at home in their "bubble" of designated members (usually family) other than for essential personal movement. Only essential services and businesses were able to open. All ECE services were closed, apart from some homebased carers who were paid an allowance to provide care for children of essential workers. Alert Level 3 (27 April to 13 May 2020) was a restricted Lockdown. The "bubble" could be expanded slightly and ECE services were able to open for children of parents who had to go to work and had no other arrangements, and for essential workers. All children were to have access to distance learning. At Alert Level 2 (from 13 May to 8 June 2020), all early childhood services were able to open, with strict hygiene requirements and plans to transition children back. Alert Level 1 (from 8 June to 12 August 2020) was portrayed by the Ministry of Education (2020) as "business as usual" for ECE services but with continued hygiene and cleaning requirements. Further Alert Levels were implemented in August (Level 3 for the city of Auckland from 12 to 30 August 2020 and Level 2 for the rest of the country). Since then, the country has moved down Alert Levels, with Auckland moving at a slower rate, until from 8 October, the whole country was at Level 1.

\section{Aotearoa New Zealand research on the impact of Covid-19 on the ECE sector}

Over 2020, Covid-19 has shaped educational policy and practice, and brought into focus strengths and vulnerabilities in the ECE sector. This article draws predominantly on research that I undertook in 2020; a June 2020 survey of managers on the impact of Covid- 
19 on the ECE sector (Mitchell et al., 2020) and subsequent interviews undertaken in August/September with 15 managers (Mitchell, Meagher-Lundberg et al., 2020). The survey and interviews illustrated the crucial role ECE services played in supporting essential workers, and teachers/kaiako, families and children through the Covid-19 pandemic.

Two research questions framed the survey and interviews:

1. What are the impacts of the Covid-19 pandemic on the Aotearoa New Zealand ECE sector?

\section{What are ECE sector responses to the Covid-19 pandemic?}

The survey was set up and distributed using the Qualtrics survey platform. Invitations to participate in the survey were emailed to managers using contact details from the Ministry of Education Directory of ECE Services on the Education Counts website. Of the 1,084 open invitations, 156 managers completed more than 83 percent of questions, the benchmark for inclusion of data. The response rate was 17 percent overall. Many managers were responsible for several or many services. Responses were received from eight kindergarten association managers responsible for 202 kindergartens, three playcentre regional managers responsible for 166 playcentres, four homebased managers responsible for 54 homebased services, and 141 education and care service managers responsible for 197 education and care centres. The latter included seven who identified as "other" - for example, a language nest. Although the response rate was fairly low, the managers came from the main types of service, and were responsible for a large number of ECE services.

Survey questions were about strategic plans and actions, teaching and learning, enrolments and attendance, staffing, and funding during lockdowns, and managers' comments about effects and meeting the challenges of a post-Covid world. Most were closed questions, and these were analysed by service type using frequency analysis. Thematic analysis (Braun \& Clarke, 2012) was used to analyse open-ended questions. Rather than seeking statistical significance, the aim was to gain a snapshot of the experiences and actions of a sample of ECE managers in response to Covid-19, and managers' views of challenges.

Following analysis of the survey data, we constructed interview questions relating to the following areas that had been identified as particularly crucial in the survey responses:

- Operational aspects of strategic/action planning, measures to support staff professional development, and staff health and wellbeing

- Brokering/connections with the community and how connections were maintained during lockdowns

- Sustainability. This set of questions asked about impacts on enrolments and attendance, hours of operation and funding

We also asked about challenges and opportunities and managers' views of government policy required to support the ECE sector. 
The interview sample was drawn from participants who answered the survey and who were willing to be contacted for a follow-up interview. This was a purposive sample, where we invited participants whose responses to the survey suggested they had detail to offer about the main themes. We aimed to recruit participants from each service type, but this was a busy time for many managers following the Covid-19 lockdowns. We were not able to recruit home-based participants. Fifteen managers coming from kindergarten associations (5), community-based education and care centres (4), private education and care centres (3), [Pasifika] immersion centres (2), and a playcentre region (1) were interviewed. Participants who were interviewed provided documentation of their strategic plans where relevant.

Research ethics approval was gained from the University of Waikato Faculty of Education Research Ethics Committee. Managers signed an informed consent form for their interviews.

Two further New Zealand studies were included in the 2021 special issue of the European Early Childhood Education Research Journal (EECERJ) entitled Plural narratives about Covid-19 and early childhood. The study by Kahuroa, Mitchell, Ng, and Johns (2021) of children's working theories about Covid-19 gives insight into how teachers used storytelling, drawing and making images with 'loose parts' to enable young children to communicate their experiences, ideas and emotions in different ways, using different senses. The study researched pedagogical work undertaken from May to August 2020 (after the first national lockdown) and again in September 2020 (after the Auckland Alert Level 3 lockdown) during the Alert Level 2, in Pakuranga Baptist Kindergarten. Most of the children at this kindergarten had come back to the kindergarten in both time periods. Information about the kindergarten, the research design and methodology is provided in the article (Kahuroa et al., 2021). A main argument emerging from findings was that artsbased approaches of drawing and story-telling became a powerful sense-making tool for children, enabling both the exploration of children's emotions, and also children's developing understanding of Covid-19 as both of these evolved over time.

The second Aotearoa New Zealand study published in the EECERJ special issue (May \& Coulston, 2021) focused on the developing practice of He Whānau Manaaki Kindergartens (HWM) during the Covid-19 nationwide lockdown in 2020. HWM is the largest kindergarten association in Aotearoa New Zealand, catering for 5,000 children, employing 900 teachers and support staff and operating 102 kindergartens. It also provides a Pacifica Etu Ao Home-Based programme and a Whānau Ora programme for Pacifica families (May \& Coulston, 2021). In their article, May and Coulston set their discussion of community outreach and new ways of providing a kindergarten experience for children at home, within the context of the early childhood policy environment and the government's 10-year action plan for the sector (Ministry of Education, 2019).

HWM is also included in an ongoing study, Refugee families in early childhood education: Constructing pathways to belonging (Mitchell et al., 2018). The HWM chief executive officer, Amanda Coulston, supplied planning documentation and the HWM newsletters written during the first national lockdown for analysis. These are used in this article, with permission, to further exemplify the actions of this kindergarten association. Informed consent, including for use of real names, was signed for the larger study. Research ethics approval was gained from the University of Waikato Faculty of Education Research Ethics Committee. 


\section{Findings}

\section{Teaching and learning}

During Alert Levels 4 and 3, teaching and learning were transformed. Essential workers, who were unable to access childcare for their children, were able to use licensed homebased childcare providers for in-home care for their children during Alert Level 4 (Ministry of Education, 2020). Many teacher-led centre-based services were open for some children during Alert Level 3, while continuing to run distance programmes for other children. Most ECE services opened in Alert Level 2.

The needs for social distancing, public health and safety measures and restrictions on ECE attendance changed the pedagogical practices and operation of services. During all the Alert Levels, many services found inventive ways to communicate with children and families and to offer opportunities for learning and support. Most managers (97 percent) marked that they provided more than one way to communicate, suggesting they tailored their communication to the situations of families (Mitchell, Hodgen et al., 2020). Some ways that teachers/kaiako used to maintain an education programme and keep in touch were:

- Teachers/kaiako making little videos of themselves for Facebook as a way to remain visible and communicate with children

- Holding a regular education programme on Zoom, ranging from story-telling to artwork to dance to music to physical exercises, and communicating directly with children

- Developing learning packs and arranging delivery to families who didn't have internet access

- Having conversations with parents about what their child was doing at home

From interviews held with teachers, May and Coulston (2021) offer a detailed picture within Whānau Manaaki Kindergatens (WMK) of new modes of teaching and learning across all five strands of the early childhood curriculum, Te Whāriki:

While the first concern for the teachers was enacting the strand of Wellbeing [Mana atua], the rahui prompted new modes of learning across the strands of Exploration [Mana autūroa] and Communication [Mana reo]. The strand of Belonging [Mana whenua] was strengthened too as families and children appreciated the regular presence of kindergarten in their homes during these weeks, but increasingly they were themselves enacting the strand of Contribution [Mana tangata] as they shared images and commentaries on their home activities and daily excursions, thereby weaving new patterns into each kindergarten and each child's curriculum whāriki. (pp. 102-103)

An unexpected spinoff from using Facebook and online learning platforms was that twoway connections between families and communities became stronger. May (2021, p. 103) reported that "Overall teachers felt more closely connected to their families," giving as an example a teacher's comment that "Some families whom we might not have been so close to before are now talking with us more. We know them better." Mitchell, MeagherLundberg et al.'s (2020) report on interviews with ECE service managers came to a similar conclusion. The authors cited an education and care centre manager: 


\begin{abstract}
It just strengthened [community connections]. It was amazing. When we came back, there was no sense of having been apart because we'd continued these relationships right throughout. We'd been in their homes through the videos they'd put up and the photos. We all felt like this - a surprise. We still try to home visit [outside lockdown]. (p. 16)
\end{abstract}

The communication methods brought teachers into family homes, and this opened the eyes of teachers to some of the richness of family lives and generated greater understanding. In a similar way, approaches to finding out about the 'funds of knowledge' (Gonzalez \& Moll, 2002); Gonzalez et al., 2005) that exist within households and communities recommend home visits by researchers. May and Coulston (2021) gave examples of ways in which parents as pedagogues invented different daily learning activities, documented these, and shared them with others. They argued that "Lessons learned by HWM teachers during lockdown were that the collaborative partnership could be strengthened in new ways that empower families as well as children" (p. 104).

Another spinoff for some children was the extra time they were able to spend at home with parents and other family members. In the small case study at Pakuranga Baptist Kindergarten, children told stories and drew pictures about their time at home (Kahuroa et al., 2021). A common theme was activities that children enjoyed doing with parents, family members and pets: "baking with my dad," baking "muffins with my mum and my sister and I put chocolate in them - they were so yummy we ate them all," playing with family pets, and with family, going for a walk or on a bike ride. After the first lockdown and on return to this kindergarten, many children reported a state of being "happy" at home. A similarly interesting finding from a US study (Kalil et al., 2020) is that parents who spent substantially more time caring for their children as a consequence of the pandemic, reported more positive parent-child interactions.

\title{
Wellbeing
}

Yet, anxiety about Covid-19, precarious employment, and/or stressful living situations have undermined wellbeing for many adults and children. Our survey found almost a third of managers marked "anxiety about returning to the service" as a reason why staff did not return to work during Alert Level 3, a finding that is consistent with April results from the Ministry of Health Covid-19 Health and Wellbeing Survey that 39 percent of participants were worried about the risk of getting Covid-19 (Ministry of Health, 2020). All managers who were interviewed spoke about the negative impact of the Covid-19 pandemic and the resulting lockdowns on staff health and wellbeing. Examples were given of raised levels of stress and anxiety, and increased sick leave and time off for some staff. In interview, one manager talked of "a sense of panic" felt by some teachers/kaiako that contributed to relationship and mental health problems. Counselling support was offered by some managers.

Managers who were interviewed said that many children in ECE settings were displaying signs of stress and anxiety. One manager said she considered using funding from the Emergency Response Fund to employ teacher aides to help settle children in their centres. This service had families whom the government had housed in their community during lockdown periods. In the small case study at Pakuranga Baptist Kindergarten, qualified teachers recognised children's needs to make sense of Covid-19. They used play-based methods and story-telling to help children to communicate with others about their experiences and extend their understandings. The authors argued that 
children's working theories about the virus, knowledge of the virus and sense of personal control over keeping themselves safe developed over time (Kahuroa et al., 2021).

Some families were facing hardship, and many ECE managers (76 percent) played a role in organising support where it was needed. They brokered support for what families needed (54\%), connected families with social services (31\%) and support organisations (31\%), and provided practical support, such as food vouchers and clothing (5\%). Some managers used Equity Funding and Targeted Funding, and accessed Community Grant funding for material support.

Stress associated with anxiety about Covid-19 and changed home environments is an international phenomenon. A US research evidence brief (Gassman-Pines \& Gennetian, 2020) cites US figures showing that between March and early November 2020, over 52 million Americans who lived in households with children experienced a loss of employment. For many others, pay and hours of work were unstable. The research evidence brief found that the combination of low family income and income instability were detrimental to children's wellbeing, and that these features had dramatically increased during the Covid-19 pandemic.

Many managers offered direct support for families/whānau, including delivery of food vouchers, and brokered social, health and financial support for families who needed it during Lockdowns 3 and 4 and into Level 2.

\section{Staffing, funding and enrolments}

Survey data showed that ECE services were facing financial pressures during Alert Levels 3 and 4, especially education and care and homebased services. While over a third of managers (38 percent) rated their financial position as about the same as before Covid19,48 percent rated it as "somewhat worse" or "much worse."

The most frequent difficulty was meeting costs of wages/salaries (19 percent), followed by staff employment conditions (13 percent), and fixed costs (13 percent). Thirty-nine percent of managers reported they were using their financial reserves. Overall, 72 percent of managers applied for the wage subsidy, and of these most (90 percent) paid the subsidy to all staff. Most (92 percent) also topped up the wage subsidy under Alert Levels 3 and 4 . Some applied for a rent reduction (16 percent) and some applied for an interest free loan for small businesses (16 percent). None of the kindergarten association managers applied for the wage subsidy, but 33 percent of playcentre managers, 75 percent of homebased managers and 77 percent of education and care managers did apply.

Yet, despite receiving financial support, 25 percent of managers said their staff were only partially paid during Alert Levels 3 and 4 . These differences were related to ownership, with 95 percent of community-based service management reporting full payment of staff, compared with 63 percent of privately-owned service management. All kindergarten management, 74 percent of education and care management and 50 percent of homebased management reported staff were fully paid.

Managers who were surveyed were asked to mark which of a list of problems were experienced by their service in the short term related to reopening. Over half the service managers marked lower enrolments or fewer children (56 percent) as problems. This was particularly the case in low-income communities. Similar to the short-term, in the longterm, lower enrolments/fewer children was the highest rated predicted problem (55 percent). These findings are consistent with a recent report analysing Ministry of Education participation and enrolment figures (Webber, 2020) which found a drop-off in 
enrolment during Level 2 after the national lockdown, although this returned to 2019 levels during Level 1 for most groups. Pacific and Māori children, and children from low EQI services (i.e., services drawing from low socioeconomic communities) were taking longer to come back.

Managers who were interviewed were asked 'What, if any, changes would you like to see in ECE policy to put your service/s and the sector on a sound footing in the future?' The main changes were:

- Funding - Most ECE managers wanted to see increased funding rates, improved funding mechanisms and pay parity. Aligned with this was a call for greater accountability for spending of government funding

- Enrolments and competition - Some full-day education and care centre managers were worried about long term sustainability. They linked this to reduced enrolments because of changed patterns of parental employment, job loss and further lockdowns. Some thought there would be centre closures and competition, as one manager put it, "to capture those children that will have been lost to those centres" (Education and care manager). The competitive environment also featured in a kindergarten association manager's view that there is "an opportunity to market ourselves as being more appropriate for the post-Covid world" in terms of being a community. This manager argued for a fullyfunded public network as a baseline to ensure quality education is available for all children whose parents want it

- Integrated centres - Several managers advocated for ECE services to be funded and supported as integrated centres, offering ECE as a hub for wider access to services that support families

- Qualified teachers - Most managers expressed the value of employing 100 percent qualified teachers. The exception was an education and care centre manager, who nevertheless wanted education and care centres to be paid at the same funding rate as kindergartens

\section{ECE working in solidarity with children, families and community}

Extraordinary efforts were made by ECE managers and teachers/kaiako to connect and work with families and community during the pandemic. Research concerning HWM (May \& Coulston, 2021; Mitchell et al., 2018) is used in this section to highlight these efforts and then discuss them as examples of working in solidarity with children, families and community.

HWM staff sprang into action after the first lockdown to go out of its way to support each other, children, families, local communities and businesses. In their first actions, they changed and reframed the term "lockdown" to "rāhui." They used Rangimarie Rose Pere's statement on rāhui to guide their approach. 
One of the first things we did was to reframe and rename the lockdown as a "rāhui." In so doing, the focus moved to taking care of ourselves for the future. This aligns with HWM values, in terms of recognising and appreciating te Ao Māori and taking a sustainable and holistic attitude to the planet and its people.

- Children enrolled in our services and their whanau (extended families) receive support for day to day living

- Children and their whānau in the wider community receive support for day to day living

\section{- HWM staff receive support for day-to-day living (HWM Strategy).}

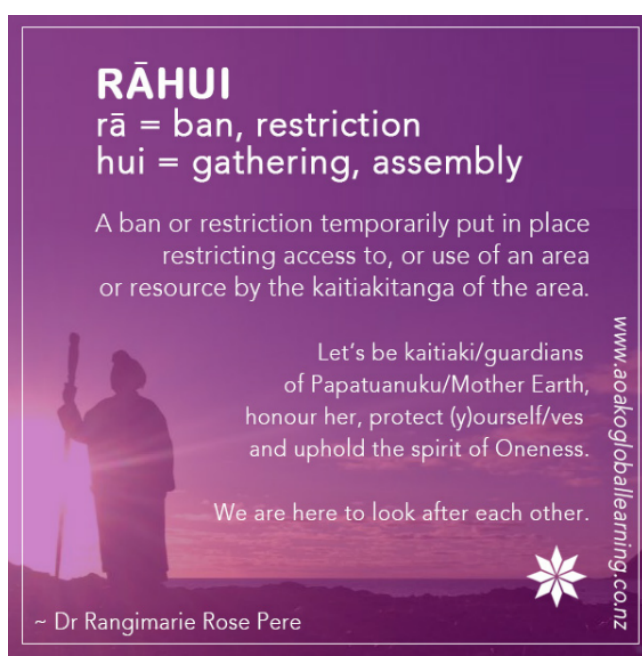

Statement from renowned educationalist Dr Rangimarie Rose Pere helped guide our approach.

The statement from Dr Rangimarie Rose Pere emphasises care and protection for self and others, and bringing people together in unity for a common good. The idea of rāhui connects with traditional Māori practices in Aotearoa New Zealand (Maxwell \& Penetito, 2007).

Staff, children and their families were the first priority for HWM. Every family was contacted individually to identify how they wanted to be communicated with and what access they had to technology. A clear expectation was that staff would remain connected with all children and families and equitable opportunities would be made for all children to engage in the ECE curriculum, either in the physical kindergarten or via distance learning. The plan was specific in getting the kindergarten team collectively to decide who would contact each whānau of the kindergarten tamariki (children). It was left up to the team because "What we are saying here is, you know your whānau best" (HWM strategy). The strategy went on to describe some valuable forms of communication and to note that some families may like only one method of communication, while others may be happy to have more than one method. An expectation was set for teaching teams to 'connect' daily with whānau and tamariki and that once whānau post, the teaching team would respond on the same day. These strategies generated a sense of "us together."

HWM teachers and staff know the reality of their kindergarten communities and were aware that many families from across their regions and across socioeconomic groups would almost immediately suffer significantly reduced income during and after the lockdowns. They used their connections to raise funds from Whānau Ora, MSD and Pasifika Futures, and along with their Targeted Funds from the Ministry of Education, they purchased food vouchers and delivered these to families through their drivers. HWM employed a community navigator to work with refugee and migrant families, translating information about the virus and brokering social and housing support where it was wanted. These efforts go beyond the usual operations of an ECE service, extending into holistic support for families outside of the day-to-day operation of the kindergartens.

Mutual support and aid were offered to staff according to their home situations and needs. Early in the pandemic a register was constructed of all staff with health conditions, pregnancy, or who were 70 years and over. The intention was to develop systems of 
support for these staff who would remain at home, as well as to manage staffing for HWM services. All permanent staff continued to be paid, as well as anyone on a fixed term contract and anyone with booked relieving hours. The group falling outside of the HWM support system, however, was casual relievers - and the national survey found also that these teachers were generally not paid, and only some were individually eligible for the wage subsidy (Mitchell, Hodgen et al., 2020).

Many businesses were struggling during the lockdowns. Solidarity with local businesses was reflected in the actions by HWM to make daily payments to suppliers to ensure they got the money they needed to keep their businesses going. As HWM's newsletter stated: "Prompt bill payment helps businesses with cash flow over a difficult period of time."

Jacinda Ardern's repeated message to New Zealanders is that we are "a team of five million." HWM exemplified a similar ideal of unity and acting together, of staff working in solidarity to support each other, families and communities. Laitinen and Pessi (2014) argue that solidarity is not focused on the wellbeing of other or you, but rather "the target of concern in solidarity can be us together" (pp. 11-12). Solidarity is premised on a concept of reciprocity, as well as a need to respond to structures and practices that are unjust. In the same book, Laitinen (2014) concludes that:

relations of mutual respect constitute a form of social unity, which can be thickened into social solidarity via patterns of mutual support and aid, with reversing roles both as a provider and receiver of benefits of cooperation. Mutual support and universal justice also form the core of moral solidarity, and the central motivations for political solidarity with victims of injustice." (p. 112)

\section{Policy context and issues highlighted by Covid-19}

The research on Covid-19 illuminated the powerful role ECE played as an essential service, and its potential to be a positive force for social cohesion and equity. Innovation and flexibility were displayed in the efforts of ECE managers and teachers/kaiako to respond to their families and communities, to support children though online and face to face education programmes, and to broker support for families. In these ways, ECE contributed to national aims to stop the spread of the virus and to bolster wellbeing.

The research also highlighted crucial issues that need attention at policy and organisational levels. Some are new issues, brought about through experiences of the pandemic. Others are enduring issues that have plagued the sector for many years and have intensified during the pandemic. The pandemic highlighted problems in allowing a competitive market approach to determine where and how ECE services are provided. Many managers are worried about their future enrolments, on which funding is based, and their ongoing viability. Some ECE services are likely to close, and others will continue to face reduced income if enrolments fall. If ECE services collapse, this will require careful planning to ensure any new services address family and community needs. A risk is the potential for ill-considered takeovers and further private corporatisation under a continuance of a market environment.

The survey findings raise unanswered questions about why some managers in education and care and homebased services reduced permanent staff pay, made some permanent staff redundant and reduced staff hours despite continued receipt of the ECE Funding Subsidy, access to the government Wage Subsidy and small business loans, and access to potential rent reductions. 
In my Opinion Piece in The New Zealand Herald (Mitchell, 2021), I highlighted the need for transformational policy:

A realignment of the role of the state in provision of ECE, where the market has gained a too powerful position and the state has been hands-off in determining the kind, nature and location of ECE services is urgently called for. Now is an ideal time to rethink the purpose of ECE, to redefine it as a public good, and to plan, fund and support it accordingly. (A31)

Similarly, Carmen Dalli, Helen May and Anne Meade (2020) captured the role played by "the best ECE services" during the pandemic as "an indispensable social infrastructure for families and for the economy" and highlighted that the ECE sector is 'shovel ready' for transformation:

Our proposal is that a systemic integrated policy infrastructure supporting children and families in their early years is as important as the economic infrastructure of wood, bricks and mortar. The early childhood sandpit not only has 'bucket and spade' at the ready; it has a blueprint for action that makes it 'shovel-ready' for transformation. It is as deserving of new money as roundabouts, road alignments and bicycle paths. (p. 2)

The "blueprint for action" is the 10-year Early Learning Action Plan (ELAP), He taonga te tamaiti. Every child a taonga (Ministry of Education, 2019). ELAP was released in December 2019, only months before the onset of Covid-19 and the national lockdown in March 2020. In the foreword to the plan, Minister of Education Chris Hipkins wrote of an aspiration for "high quality learning" and his commitment to "leading the improvements set out here for our early learning system, so it enables all of our children to learn and thrive and experience a good life as New Zealanders" (p. 5). The plan set timelines and actions for policy, which are directly relevant to the lessons learned during the Covid-19 pandemic. Actions include planned steps towards 100 percent qualified teachers in teacher-led ECE settings, a mechanism to improve the levels and consistency of teachers' salaries and conditions across the early learning sector, and improving staff ratios for under-threes. The plan's Objective 2 includes action to develop advice "to facilitate wrap around health and social services" (p. 21). In addition, the Terms of Reference for the action plan working group stated: "The Government is committed to investing in and backing our world-class, public education system for all students. This involves turning the tide away from a privatised, profit-focused education system" (Hipkins, 2018, p. 4).

May and Coulston (2021) argue that the plan was meant to be transformational, but that gains made in the government's 2020 budget were "miniscule":

The 2020 Budget was delivered during lockdown and, except for restoring the subsidies for ECE centres with $100 \%$ qualified staff, focused primarily on the Covid19 emergency. While this was a bonus for ECE it was miniscule compared to the billions of dollars 'saved for a rainy day' being rolled out to fund the so-called shovel ready infrastructure projects intended to boost the economy with new job opportunities. The long awaited gains for ECE had been diverted. (p. 104) 
A leap forward in thinking is called for that recognises ECE as a public service and the responsibility of government to plan, fund and support it accordingly. In the final section of this article, the consequences of three decades of neoliberalism, privatisation and marketisation are briefly discussed, as is some highly troubling and unacceptable ECE management and employment behaviour that was uncovered after the national lockdown, and a reimagined vision for ECE is put forward.

\section{A reimagined vision for ECE in Aotearoa}

During the 1980s, the Labour Government implemented sweeping reforms in New Zealand to reduce the role of the state and privatise public services, and these reforms were intensified in the 1990s under the subsequent National Government (Kelsey, 1997). In parallel, within the ECE sector, homebased and education and care services grew rapidly in number and became increasingly privatised and marketised. These are settings where New Zealand children are often spending long hours and from a young age. In this environment, as in many OECD countries, the education and care offered by these ECE services has become increasingly subject to commodification, put up for sale in competition with other ECE services. Commodification is highly visible in New Zealand's competitive advertising, in financial incentives to get families to enrol their child - first month free, discounts for new customers, nappies supplied - and also in financial penalties for debt, for irregular attendance, and for being late in picking up a child.

Consequences of privatisation and commodification are graphically demonstrated in the following case where, very recently in 2020, ten ECE centres from a private chain (Discoveries Educare) of 11 centres were permanently closed for failing to meet standards (Kronast, 2020). A Ministry of Education official told a Newshub reporter of complaints that had been received during the year. "The complaints included allegations of physical or emotional injuries inflicted on children, including verbal abuse, isolation of children and physical harm, poor curriculum quality, a lack of staff and poor learning support" (Kronast, 2020, not paginated). Advertising on the Discoveries website (2020 Discoveries Educare, 2020) paints an astoundingly erroneous picture, designed to attract parents. Entitled "Discover the joy of learning. Education for infants, toddlers and pre-schoolers" it claims, "At Discoveries Educare, we understand that your children are our future. Discoveries Educare is a childcare organisation with 11 centres throughout Auckland, each staffed with a team of passionate and dedicated teachers committed to quality education at every age and every stage." At the same time, an advertisement by Discoveries in the Education Gazette called for "an unqualified teacher" with flexibility to be assigned to various locations. Lures were advertised for parents to access "30 hours free," but there were catches, such as enrolments for 30 hours "no more no less" and across five days, no variations to start and finish times, child must attend for five days per week with no frequent absences. "Late pick up fees apply." All these aspects are about gaining maximum child funding from the government. Five of the closed centres and the management received a total of NZ\$460,000 in wage subsidies (Work and Income Te Hiranga Tangata, 2020). How have the ECE wage subsidy funding and parent fees been spent over the year by Discoveries Educare? What profits have been accrued by the owners? What was the value for children and families in attending these centres? are three questions that need to be asked. Educare in these settings was treated as a commodity, marketed and sold to parents. Accountability for spending of government funding and profit-making for private gain by private businesses has been highlighted as problematic over many years (Mitchell, 2019). In their policy suggestions, interview 
respondents called for greater accountability for spending to ensure funding went to intended purposes. This was expressed especially in relation to for-profit providers (Mitchell, Meagher-Lundberg et al., 2020).

In another media-profiled case, long-term abusive practices towards children carried out by the manager were claimed. It was stated that parents and former teachers from Pitter Patter Education Centre in Feilding:

have told the Ministry of Education that the owner and manager of a childcare centre in Feilding locked toddlers in rooms, fed children mouldy food and smacked them. The Pitter Patter Education Centre had its licence suspended for three weeks in November while the Ministry of Education (MoE) investigated complaints spanning at least five years." (Cook, 2020, 17 December)

The Ministry referred the complaints to the police and the Teaching Council and the manager was suspended from contact with children. A raft of further complaints and 33 breaches of licence, including "dirty bedding and rooms, bad food, a lack of fresh air and piping hot taps within reach of toddlers" were highlighted in a further report on February 2021 (Cook, 2021, 18 February).

The Covid-19 pandemic has highlighted that neoliberalism, and associated marketisation, privatisation and commodification of ECE cannot address the big policy issues that confront the ECE sector and the wider community. In the 2020 BBC Reith Lectures, Mark Carney (Carney, 2020), a former central banker in Canada and Governor of the Bank of England, assesses how under neoliberalism the world has come to prioritise financial values over human values. He portrays value as "the regard that something is held to deserve, its importance, its worth, its usefulness. Value isn't necessarily constant, but, rather, specific to time and situation." According to Carney, there is considerable evidence that commodification can corrode the value of the activity being priced. He describes "fines for late pickups of children from day care" as a "fee for extra hours" where "money crowds out civic norms." In this scenario, "civic and social virtues atrophy with disuse," whereas, he argues, evidence suggests they "would grow like muscles with regular exercise." Kamenarac (2019), in her recent University of Waikato doctoral thesis, analysed how teachers from for-profit corporate education and care centres started to align with profit motives of business owners before allegiance to the ECE profession. As Carney argues, "When we outsource civic virtue to pay third party providers, we narrow the scope of society and encourage people to withdraw from it."

Mariana Mazzucato (2018) argues that a contested debate about value is needed, and a starting point is the right balance between the market and the state. A realignment of the role of the state in provision of ECE, where the market has gained a too powerful role and the state has been hands off in determining the kind, nature and location of ECE services that are provided, is urgently called for. My hope is that a debate about values in early childhood education will enable us to turn our backs on privatisation, marketisation and commodification and its associated problems.

My reimagined vision for ECE is for a conception of ECE that takes as its foundational values that children are citizens, and that education is valued as a public good and a child's right. ECE services are conceptualised as community organisations playing an important role in fostering a democratic and bicultural society. Aspirations for children to develop as proactive, informed citizens of a bicultural Aotearoa will be realised in practice. Solidarity and commitment to the public good are hallmarks of operation. No one paid 
Whānau Manaaki Kindergartens to check out and care for their staff and families during the Covid-19 lockdown, or to go out of their way to find financial support for those who were in hard economic times. It was a response derived from a view of ECE as a community responsibility and public good, not a private commodity. It illustrated a generalised reciprocity, a kind of "community-minded give and take" (Press et al., 2018, p. 335).

The Quality Public Early Childhood Education Project (May \& Mitchell, 2009), undertaken with nine community-based organisations as a response to a policy environment where community-based services were disadvantaged and struggling, put forward worthwhile proposals to create alternatives to the marketised and privatised systems that have been shown to be problematic. The project group proposed shifting from a market approach of provision to what it termed "a partnership model" where ECE services work with the government and community to build a coherent network of provision in every community. A focus would be on the right of the child as a citizen to participate in free ECE, and to access high-quality, community-based ECE. Within a "partnership model," new forms of provision could be created, funded and supported. In a post-pandemic world, integrated centres offering ECE as a hub for wider access to services that support families would offer a worthwhile way of supporting family wellbeing (Clarkin-Phillips \& Carr, 2012).

Community-based ECE services would foster participatory democracy through emphasising participation in decision-making and collective responsibility. Sander and Putnam (2010) write of the expansion of civic and social engagement for youth after the 9/11 attacks, although with "lower-class youth growing less involved while better-off youngsters become more involved" (p. 9). Can "networks of community engagement" be expanded through participation in community-based ECE post-Covid-19, and for people from all classes and ethnicities? Through the Covid-19 alert levels, people experienced social isolation, anxiety and stress. Many people - doctors, nurses, supermarket workers, ECE teachers/kaiako, foodbank distributors etc. - played essential roles, showing that we can rely on each other for help. The example of Whānau Manaaki Kindergartens shows how a community-based kindergarten organisation supported others well beyond its expected purpose. Effective government decision-making played a crucial role. Building civic and community engagement is especially important in a post-Covid world, and one where community-based ECE services are well-equipped to contribute because of their collective decision-making structures and philosophical positionings. My reimagined vision would adopt proposals for strengthening community-based and public provision that offers opportunity for civic and community engagement, premised on empowered children and families.

The government funding system needs to ensure that government funding goes into educating the child and supporting the family. This was another recommendation from the Quality Public Early Childhood Education Project (May \& Mitchell, 2009) and also a recommendation from managers who were interviewed about the impact of Covid-19 (Mitchell, Meagher-Lundberg et al., 2020). Controls on fee charging and enrolment policies, scrutiny of full financial statements by government and the ECE service community, and refusal to fund publicly listed ECE companies would deter potential for private profit. Recognition is urgently needed of the value of ECE teachers' work as skilled, complex and demanding and on a par with the work of teachers in kindergartens and schools, through pay parity with schoolteachers, and appropriate working conditions. A shift in state responsibility for the whole ECE teaching workforce to parallel their role in 
relation to kindergarten teachers' employment negotiations, where the Secretary of Education is a party to the employment agreement, would enable pay parity and appropriate working conditions to be achieved.

In a reimagined vision, the capacity of teachers/kaiako to think and act critically will be developed to the fullest. Giroux (2020) makes a case for educators as "public intellectuals willing to connect pedagogy with the problems of public life, a commitment to civic courage, and the demands of social responsibility" (p. 4). Likewise, Brostrom (2013) has argued that curricula are needed to help children "act in a future society as critical-democratic subjects" (p. 254). To end, my hope is that the Covid-19 pandemic will provoke new thinking about how the world should be and what a meaningful system of ECE would look like within a reimagined world.

\section{References}

2020 Discoveries Educare. (2020). Discoveries Educare.

https://www.discoverieseducare.co.nz/

Braun, V., \& Clarke, V. (2012). Thematic analysis. In H. Cooper (Ed.), APA handbook of research methods in psychology: Vol 2 research designs: American Psychological Association.

Brostrom, S. (2013). Understanding Te Whäriki from a Danish perspective. In J. Nuttall (Ed.), Weaving Te Whäriki. Aotearoa New Zealand's early childhood curriculum document in theory and practice. (2nd ed., pp. 239-257). New Zealand Council for Educational Research.

Carney, M. (2020). The Reith lectures: How we get what we value.

https://downloads.bbc.co.uk/radio4/reith2020/Reith_2020_Lecture_1 transcript.pdf

Clarkin-Phillips, J., \& Carr, M. (2012). An affordance network for engagement: Increasing parent and family agency in early childhood education. European Early Childhood Education Research Journal, 20(2), 177-187.

Cook, C. (2020, 17 December). Pitter Patter education centre in Feilding under investigation after raft of allegations.

https://www.stuff.co.nz/national/300186081/pitter-patter-education-centre-in-feildingunder-investigation-after-raft-of-allegations?rm=a

Cook, C. (2021, 18 February). Education Ministry finds 33 breaches at Pitter Patter childcare centre in Feilding. https://www.rnz.co.nz/news/national/436642/educationministry-finds-33-breaches-at-pitter-patter-childcare-centre-in-feilding

Dalli, C., May, H., \& Meade, A. (2020). Opinion piece: Early learning plan 'shovel ready' www.newsroom.co.nz/early-learning-plan-shovel-ready-now

Gassman-Pines, A., \& Gennetian, L. A. (2020). COVID-19 job and income loss jeopardize child well-being: Income support policies can help. SRCD Child Evidence Brief, 9(December). https://www.srcd.org/research/covid-19-job-and-income-loss-jeopardizechild-well-being-income-support-policies-can-help 
Giroux, H. (2020). On critical pedagogy (2nd ed.). Bloomsbury Academic.

Gonzalez, N., \& Moll, L. C. (2002). Cruzando el puente: Building bridges to funds of knowledge. Educational Policy, 16, 623-641. http://epx.sagepub.com/cgi/content/abstract/16/4/623

Gonzalez, N., Moll, L. C., \& Amanti, C. (Eds.). (2005). Funds of Knowledge: Theorizing practices in households, communities and classrooms. Lawrence Erlbaum Associates.

Hipkins, C. (2018). Terms of reference: Development of a 10 year strategic plan for early learning.

http://www.education.govt.nz/assets/Documents/Ministry/consultations/Strategic-

Plan-ToR.pdf

Kahuroa, R., Mitchell, L., Ng, O., \& Johns, T. (2021). Children's working theories about COVID-19 in Aotearoa New Zealand. European Early Childhood Education Research Journal, 29(1). https://doi.org/10.1080/1350293X.2021.1872672

Kalil, A., Mayer, S., \& Shah, R. (2020). Impact of the COVID-19 crisis on family dynamics in economically vulnerable households. https://bfi.uchicago.edu/wpcontent/uploads/2020/10/BFI WP 2020143.pdf

Kamenarac, O. (2019). Discursive constructions of teachers' professional identities in early childhood policies and practice in Aotearoa New Zealand: Complexities and contradictions. (Doctoral thesis). The University of Waikato.

https://hdl.handle.net/10289/12363

Kelsey, J. (1997). The New Zealand experiment: A world model for structural adjustment? Auckland University Press: Bridget Williams Books.

Kronast, H. (2020). Five Discoveries Educare ECE centres forced to close after failing to meet standards, all but one left. https://www.newshub.co.nz/home/new-

zealand/2020/12/five-discoveries-educare-ece-centres-forced-to-close-after-failing-tomeet-standards-all-but-one-left.html

Laitinen, A. (2014). From recognition to solidarity: Universal respect, mutual support, and social unity. In A. Laitinen \& A. B. Pessi (Eds.), Solidarity: Theory and practice. Retrieved from Proquest Ebook Central.

Laitinen, A., \& Pessi, A. B. (2014). Solidarity: Theory and practice. An introduction. In A. Laitinen \& A. B. Pessi (Eds.), Solidarity: Theory and practice. Retrieved from Proquest Ebook Central.

Maxwell, K., \& Penetito, W. (2007). How the use of rāhui for protecting taonga has evolved over time. MAI Review, 2(Intern Research Report). 
May, H., \& Coulston, A. (2021). He Whānau Manaaki kindergartens, Aotearoa New Zealand: A pandemic outreach in new political times. European Early Childhood Education Research Journal, 29(1), 96-108.

https://doi.org/10.1080/1350293X.2021.1872675

May, H., \& Mitchell, L. (2009). Strengthening community-based early childhood education in Aotearoa New Zealand.

http://www.nzare.org.nz/portals/306/images/Files/May\%20and\%20Mitchell\%20(2009) \%20Report QPECE project.pdf

Mazzucato, M. (2018). The value of everything: Making and taking in the global economy. Penguin Random House.

Ministry of Education. (2019). He taonga te tamaiti. Every child a taonga. Early learning action plan 2019-2029. https://conversation-space.s3-ap-southeast-

2.amazonaws.com/SES 0342 ELS 10YP Final+Report Web.pdf

Ministry of Education. (2020). He pānui kōhungahunga: The early learning bulletin.

Special edition Covid-19-related bulletins. https://www.education.govt.nz/early-

childhood/how-the-ministry-works/early-learning-bulletin/

Ministry of Health. (2020). COVID-19 health and wellbeing survey.

https://www.health.govt.nz/our-work/diseases-and-conditions/covid-19-novelcoronavirus/covid-19-novel-coronavirus-resources-and-tools/covid-19-health-andwellbeing-survey

Mitchell, L. (2019). Turning the tide on for-profit provision in early childhood education. New Zealand Annual Review of Education, 24, 78-91.

Mitchell, L. (2021, 21 January). Time for a reset on early childhood education. Opinion. The New Zealand Herald, p. A31.

Mitchell, L., Hodgen, E., Meagher-Lundberg, P., \& Wells, A. (2020). Impact of Covid-19 on the early childhood education sector in Aotearoa New Zealand: Challenges and opportunities. An initial survey of managers. https://www.waikato.ac.nz/wmier/centresand-units/early-years-research/where-have-we-published

Mitchell, L., Meagher-Lundberg, P., \& Wells, C. (2020). Impact of Covid-19 on the early childhood education sector in Aotearoa New Zealand. Report 2: Interviews with managers. https://www.waikato.ac.nz/ data/assets/pdf file/0006/567285/Impact-ofCovid-19 Report-2 Final 2020-12-09.pdf

Mitchell, L., Rameka, L., Bateman, A., Atatoa-Carr, P., Carr, M., \& Ang, L. (2018). Refugee families in early childhood education: Constructing pathways to belonging. https://www.waikato.ac.nz/wmier/projects/early-yearsresearch/refugeefamiliesinearlychildhoodeducationconstructingpathwaystobelonging 
New Zealand Government. (2020). Alert system overview. https://covid19.govt.nz/covid19/alert-system/alert-system-overview/

Press, F., Woodrow, C., Logan, H., \& Mitchell, L. (2018). Can we belong in a neo-liberal world? Neo-liberalism in early childhood education and care policy in Australia and New Zealand. Contemporary Issues in Early Childhood, 19(4), 328-339.

Sander, T. H., \& Putnam, R. D. (2010). Still bowling alone. The post-9/11 split. Journal of Democracy, 21(1), 9-16. https://doi.org/10.1353/jod.0.0153

Webber, A. (2020). How participation in early learning is affected by COVID-19. https://www.educationcounts.govt.nz/ data/assets/pdf file/0015/204603/Howparticipation-in-early-learning-is-affected-by-COVID-19.pdf

Work and Income Te Hiranga Tangata. (2020). Covid-19 wage subsidies - employer search. https://services.workandincome.govt.nz/eps/search

Linda Mitchell is professor of education at the University of Waikato. Her current research focuses on constructs of belonging for refugee and immigrant families and the role of early childhood education in supporting bicultural belonging in Aotearoa New Zealand. A longstanding research interest is in the damaging impact of neoliberalism, marketisation and privatisation on early childhood education and the need for alternative policy frameworks. She argues for early childhood centres to be conceptualised as public services, that promote principles of social justice, respect for rights and an aim to support children growing up in a democracy.

Email: linda.mitchell@waikato.ac.nz

ORCiD: https://orcid.org/0000-0001-9428-3192 